\title{
Effect of Temperature Synthesis on the Catalytic Performance of Zirconium Pillared Interlayered Clays for Phenol Oxidation
}

\section{Mnasri-Ghnimi $\mathbf{S}^{1^{*}}$ and Frini-Srasra $\mathbf{N}^{1,2}$}

${ }^{1}$ Laboratoire de Physico-chimie des Matériaux Minéraux et leurs Applications, Centre National des Recherches en Sciences des Matériaux, Technopole Borj Cédria, BP 95-2050 Hammam lif, Tunisia

${ }^{2}$ Départements de Chimie, Faculté des Sciences de Tunis, 1060 Tunis, Tunisia

"Corresponding author: Mnasri-Ghnimi S, Laboratoire de Physico-chimie des Matériaux Minéraux et leurs Applications, Centre National des Recherches en Sciences des Matériaux, Technopole Borj Cédria, BP 95-2050 Hammam lif, Tunisia, Tel: +21671430470; E-mail: saidamnasri@gmail.com

Rec date: November 20, 2017; Acc date: November 24, 2017; Pub date: December 01, 2017

Copyright: $\odot 2017$ Mnasri-Ghnimi S, et al. This is an open-access article distributed under the terms of the Creative Commons Attribution License, which permits unrestricted use, distribution, and reproduction in any medium, provided the original author and source are credited.

\begin{abstract}
Zirconium pillaring solutions have been prepared at different temperatures in order to investigate their effect on the physico-chemical properties of the resulting pillared clays. It has been verifed that variation in the temperature affects the properties of the pillared clays obtained. The resulting materials exhibited basal spacings in the range of 18-19.5 $\mathrm{A}^{\circ}$, except for pillared interlayed clays (PILCs) prepared at a temperature $\geq 75^{\circ} \mathrm{C}$, whose structure collapsed below $550^{\circ} \mathrm{C}$. Improvements in specific surface area $\left(200-250 \mathrm{~m}^{2} \mathrm{~g}^{-1}\right)$ were achieved. Fixed zirconium ranges between 15.3 and $17 \%$. Stronger Bronsted acid sites were developed into the Zr-PILCs materials, in addition to Lewis sites, even at $500^{\circ} \mathrm{C}$, as indicated by the desorption of $n$-butylamine as a probe molecule. These acid sites were strong enough to convert phenol to $\mathrm{CO}_{2}$ and $\mathrm{H}_{2} \mathrm{O}$.
\end{abstract}

Keywords: Zr-pillared clays; Heterogeneous catalysis; Catalytic oxidation; Phenol; Hydrogen peroxide

\section{Introduction}

It is clear today that sustainable development in any society requires chemical processes to be cleaner and cleaner, which involves avoiding the formation of harmful residual subproducts [1]. This is not always possible. Thus, it is necessary to turn to the implementation of proper technologies for the elimination of such residues. Organic compounds are among the main pollutants found in waste waters, such as phenol, substituted phenols (chlorophenol, nitrophenol), pesticides, and herbicides, among others [2-4]. Phenol in particular is considered to be one of the most toxic pollutants [3,5]. Catalytic wet air oxidation (CWAO) is an efficient technique to eliminate organic compounds such as phenols [6]. Homogenous and heterogeneous catalysts were developed using strong oxidants such as $\mathrm{H}_{2} \mathrm{O}_{2}$ [7-13]. Homogeneous catalysts $\left(\mathrm{Cu}^{2+}\right.$ and $\left.\mathrm{Fe}^{2+}\right)$ must be separated from the aqueous solution after the reaction, which in turn increases the costs of the process and brings about further contamination through the dissolved metal ions. The use of heterogeneous catalysts constitutes a true alternative for the phenol oxidation in aqueous medium if the catalyst is stable in an aqueous medium and selective towards the formation of $\mathrm{CO}_{2}$ and $\mathrm{H}_{2} \mathrm{O}$ [14]. Pillared clays represent a new class of microporous materials that have potential catalytic application in phenolic molecule degradation [15]. Pillared clays prepared by the intercalation of inorganic cationic clusters into clay layers and subsequent thermal activation, have been extensively investigated as catalysts and catalyst supports. Pillared clays provide many advantages over the parent clays. The uniform pore structure of pillared clay combined with its acidity and thermal stability has been crucial for many organic and shape selective reactions. By using suitable chemical methods, polycations obtained from the polymerization of multivalent inorganic cations have been intercalated into the interlayer region of clays. Among all the pillared clays, clays pillared with inorganic polycations of $\mathrm{Al}$ and $\mathrm{Zr}$ have been most widely investigated due to their relatively simple way of preparation and variety of catalytic applications. In the case of $\mathrm{Zr}$ PILCs, it was reported that the polycationic pillaring species is $\left(\mathrm{Zr}_{4}(\mathrm{OH})_{8}\left(\mathrm{H}_{2} \mathrm{O}\right)_{16}\right)^{8+}$ [16-20]. The final property of the $\mathrm{Zr}$-pillared clays depends upon several factors such as the method of intercalation. The intercalation of clays with zirconium oligomers has been widely studied. Nevertheless, few preparation methods for zirconium intercalated. Two main methods of preparation of $\mathrm{Zr}$ pillared inter layered clays have been reported in the literature, described a method in which a clay suspension is mixed with a fresh $\mathrm{ZrOCl}_{2}$ solution to produce, upon hydrolysis at room temperature, a zirconium oligomer whose structure is the square planar complex $\left[\mathrm{Zr}_{4}(\mathrm{OH})_{8}\left(\mathrm{H}_{2} \mathrm{O}\right)_{16} \mathrm{Clz}\right]$ $(8-z)+[21]$. Bartley and Burch; Ohtsuka et al. considered the reflux at $100^{\circ} \mathrm{C}$ of $\mathrm{ZrOCl}_{2}$ solutions before and after addition to the clay suspension, to favour the polymerization of the zirconium complex $[22,23]$. The main drawback of these methods is the longer preparation time. Therefore, effort were made to reduce the intercalation period by using a novel route, which comprise the use of ultrasoniccation and microwave techniques for preparation of Zr-pillared clays [24-26]. In the synthesis of zirconia pillared clays, one of the principal pillared clays quoted in the literature, zirconium oxychloride solutions are commonly used as the pillaring precursors [27,28]. Zirconium acetate was also used as $\mathrm{Zr}$ precursor, in order to minimize dealumination of the clay structure but, few papers describing the pillaring with zirconium oligomers using $\mathrm{ZrCl}_{4}$ as a source of zirconium species has been published [19,29-31] to the best of the authors' knowledge. Genesis of the metal oxyhydroxide polycations, washing and drying steps are also key factors in controlling the nature of the zirconium species present in solution, which are responsible for the intercalation process [32-37]. The aim of the present work is two-fold: first, to study the solids obtained by pillaring Tunisian bentonite with zirconium polycations using $\mathrm{ZrCl}_{4}$ as a precursor. In other words, to study the effects of the temperature of the pillaring solution on the structural and 
textural properties of $\mathrm{Zr}$ pillared Tunisian bentonite. Then, the application of the pillared bentonite as a catalyst in the phenol oxidation reaction is also investigated.

\section{Experimental Conditions}

The dye concentrations were measured using ELICO SL 27 VIS Spectrophotometer. Brilliant Green (BG) is used in the adsorptive technique was obtained from HI media laboratory pvt ltd, Mumbai. The coconut shells were received from domestic waste.

\section{Preparation of Na-bent}

In order to prepare the pillared materials, the bentonite was purified by conventional sedimentation. To eliminate the calcite $(23 \%$, measured by calcimetry), crude bentonite was first treated with $0.3 \mathrm{M}$ $\mathrm{HCl}$. The pretreated sample was then stirred for $12 \mathrm{~h}$ at room temperature and at a rate of $100 \mathrm{~g} \mathrm{l}^{-1}$ in a molar solution of sodium chloride. The suspension was then centrifuged at $3000 \mathrm{rev} \mathrm{min}^{-1}$. The ion exchange was repeated five times. After the final centrifugation, the clay exchanged with sodium was washed by centrifugation and then separated from its impurities by sedimentation/decantation. Finally, removal of the excess chloride by dialysis with distilled water gave Nabentonite (Na-Bent). The chemical composition of the $\mathrm{Na}$ exchanged purified fraction, expressed in the oxide form $/ 100 \mathrm{~g}$ of the calcined sample, is $\mathrm{SiO}_{2}$ 61.38, $\mathrm{Al}_{2} \mathrm{O}_{3} 24.80, \mathrm{Fe}_{2} \mathrm{O}_{3}$ 8.03, $\mathrm{Na}_{2} \mathrm{O}$ 3.06, $\mathrm{MgO}$ 1.38, $\mathrm{CaO} 0.13, \mathrm{~K}_{2} \mathrm{O}$ 1.40. The structural formula of $\mathrm{Na}-\mathrm{Bent}$ was found to be: ${ }^{\mathrm{IV}}\left[\mathrm{Si}_{7.43} \mathrm{Al}_{0.57}\right]^{\mathrm{VI}}\left[\mathrm{Al}_{2.96} \mathrm{Fe}_{0.73} \mathrm{Mg}_{0.24}\right] \mathrm{Na}_{0.71} \mathrm{~K}_{0.21} \mathrm{Ca}_{0.01} \mathrm{O}_{22}$. Its cation exchange capacity (CEC) is $78 \mathrm{meq} / 100 \mathrm{~g}$ and its specific surface area is: $\mathrm{SBET}=107 \mathrm{~m}^{2} \mathrm{~g}^{-1}$.

\section{Synthesis of the pillared clays}

A zirconium polycation solution was prepared at different temperature $\left(25^{\circ} \mathrm{C}, 40^{\circ} \mathrm{C}, 50^{\circ} \mathrm{C}, 75^{\circ} \mathrm{C}\right.$, and $\left.100^{\circ} \mathrm{C}\right)$ by slow titration of a $\mathrm{ZrCl}_{4}$ solution $(0.1 \mathrm{M})$ with a solution of $\mathrm{NaOH}(0.2 \mathrm{M})$ under vigorous stirring, using a $\mathrm{OH} / \mathrm{Zr}$ mole ratio equal to $4(\mathrm{pH}=2.8)$. This value of $\mathrm{pH}$ allows to a thermally stable zirconium pillared clays with controlled morphology, texture and acid properties (saida and frini surface engeneering). The pillaring solutions were then aged for 24 hours at $25,40,50,75$, and $100^{\circ} \mathrm{C}$. The pillared interlayered clays were obtained by addition of various aqueous solutions of hydroxyzirconium to $5 \mathrm{~g}$ of the Na-Bent clays, using a ratio $\mathrm{Zr} /$ clay of 10 $\mathrm{mmol} / \mathrm{g}$. This ratio is the most widely used in the literature either for Zr-PILCs or Al-PILCs [18,29,38-47]. The suspensions were kept in contact with the solution for 24 hours at $25,40,50,75$, and $100^{\circ} \mathrm{C}$ ), washed by centrifugation and dialysis (five times) and dried at $60^{\circ} \mathrm{C}$, then calcined at $550^{\circ} \mathrm{C}$ for $2 \mathrm{~h}$ according to the liturature $[30,48,49]$. The samples are designated by the following nomenclature: Zrx-Bent, where the subindex indicates the temperature of pillaring solution.

\section{Physico-chemical characterization}

The X-ray diffraction (XRD) study was done in a 'PANalylitical X'Pert HighScore Plus' device, which operates with $\mathrm{Cu}$ Ka radiation.

$\mathrm{N}_{2}$ adsorption-desorption experiments were carried out at $-196^{\circ} \mathrm{C}$ on a Quantachrome, USA instrument. The $\mathrm{N}_{2}$ isotherms were used to determine the specific surface areas (SBET) using the BET equation. The micropore volume was determined using the $t$-plot method and the total pore volume of the samples, $\mathrm{V}_{\mathrm{t}}$, was calculated at $\mathrm{P} / \mathrm{P}_{0}=0.99$ Before each measurement the samples were outgassed for $2 \mathrm{~h}$ at $130^{\circ} \mathrm{C}$.
The chemical analysis of the starting material and modified samples was determined by atomic adsorption, the spectrometer used is of the type AAS Vario.

Cation exchange capacity was determined by Kjeldhal method. Samples of $200 \mathrm{mg}$ were exchanged with the ammonium acetate (1 M) three times and then washed with anhydrous methanol; a final wash was performed with deionized water three times. The amount of ammonium retained was determined using a unit Kjeldhal. The CEC is expressed as milli-equivalent per gram of the calcined sample.

Potentiometric titration measurements were performed with a Titrando 716 automatic titrator (Metrohm) at ambient temperature and aerated medium. The PZC value and acid centre were determined following the method described by Sposito [50]. Using the proton adsorption or proton charge $\sigma \mathrm{H}\left(\mathrm{mol} \mathrm{m}^{-2}\right)$ the following formula was applied,

$$
\sigma H\left(\mathrm{molm}^{-2}\right)=\frac{v}{m} S\left\{\left(\left|H^{+}\right|_{b}-\left|H^{+}\right|_{a}-K_{w}\left(\frac{1}{\left|H^{+}\right|_{b}}-\frac{1}{\left|H^{+}\right|_{S}}\right)\right\}\right.
$$

Where $\mathrm{V}$ is the volume of electrolyte solution equilibrated with clay $(50 \mathrm{ml}),\left[\mathrm{H}^{+}\right]$is the solution proton concentration $(\mathrm{M}), \mathrm{KW}$ is the dissociation product of water (10-14), subscripts ' $s$ ' and ' $b$ ' refer to sample and blank solution, mis the mass of sample used $(0.05 \mathrm{~g})$, and $\mathrm{S}$ is the specific surface area $\left(\mathrm{m}^{2} \mathrm{~g}^{-1}\right)$.

The PZC values were also determined following the method described by, mass titration experiments were performed followed by the $\mathrm{pH}$ drift until a steady value was achieved [51]. Each portion of $0.05 \mathrm{~g}$ of a dry clay sample was added to $50 \mathrm{~mL}$ of $\mathrm{NaCl}$ solution at different ionic strength with the $\mathrm{pH}$ between 3 and 10. After each addition, the $\mathrm{pH}$ was recorded after an "equilibrium time" of about 15 minutes. Then a new amount of the sample was introduced to make changes in the $\mathrm{pH}$. This procedure was repeated until no $\mathrm{pH}$ change occurred.

Brönsted and Lewis acid centers were determined by FT-IR spectroscopy method on the basis of adsorption of butylamine. With this method $10 \mathrm{ml}$ of prepared butylamine in a cyclohexane solution was added to $0.1 \mathrm{~g}$ of catalyst. The mixture was shaken at room temperature. After drying at room temperature for $48 \mathrm{~h}$, each sample was outgassed at different temperatures. FT-IR spectra were recorded in the region $1800-400 \mathrm{~cm}^{-1}$ on a Perkin-Elmer infrared Fourier transform spectrometer using the $\mathrm{KBr}$ pellet technique.

\section{Catalytic study}

The catalytic oxidation reaction of phenol in a diluted aqueous medium was carried out in a batch reactor (pyrex) with a capacity of $250 \mathrm{~mL}$, open to the atmosphere, thermostatted at $25^{\circ} \mathrm{C}$, thoroughly stirring and constantly monitoring the $\mathrm{pH}$ variations by means of an electrode. The device featured an automatic dosimeter (Dosimat 725 Metrohm) for the continuous addition of the oxidizing agent (hydrogen peroxide solution). For each test the reactor was loaded with $100 \mathrm{~mL}$ of a phenol solution $\left(5 \times 10^{-4} \mathrm{M}\right)$ and $0.5 \mathrm{~g}$ of catalyst. The hydrogen peroxide solution $(0.5 \mathrm{M})$ was added at a $2 \mathrm{~mL} \mathrm{~h}^{-1}$ flow. The $\mathrm{pH}$ was continuously adjusted to 3.7 with dilute aqueous $\mathrm{HCl}$ or $\mathrm{NaOH}$ solutions $(0.1 \mathrm{M})$ and an air flow was introduced in the reactor at a ratio of $2 \mathrm{~L} \mathrm{~h}^{-1}$. The course of the phenol conversion and the appearance of the intermediate compounds were followed by highperformance liquid chromatography (HPLC) by means of a Waters 600 E liquid chromatographer equipped with an aminex HPX $87 \mathrm{H}$ 
(Biorad) column. The evaluation of the total organic carbon (TOC) was carried out with a Dohrman DC-80 device.

\section{Results}

\section{Characterization of samples}

XRD: The oriented powder XRD traces of the pillared clays calcined at $550^{\circ} \mathrm{C}$ are shown in Figure 1 . The results indicate that the modification carried out on the clay leads, when the pillaring solutions were prepared at a temperature under $75^{\circ} \mathrm{C}$, to the successful pillaring of the material. In fact, the shift of the d001 basal spacing from $10 \mathrm{~A}^{\circ}$ (starting clay) to $18.22-19.5 \mathrm{~A}^{\circ}$ (Table 1 ) confirms the modification via pillaring. And, indicating that the layers of the clay are homogeneously spaced. However, in the case of samples prepared with a high temperature $\left(75^{\circ} \mathrm{C}\right.$ and $\left.100^{\circ} \mathrm{C}\right)$, it must be emphasised that the clay structure becomes disordered, thus giving products on which the (001) reflection peaks disappear. Basal spacings of the samples, at $25^{\circ} \mathrm{C}$ and calcined at $550^{\circ} \mathrm{C}$, are presented in Table 1.

The preparation of the pillared clays at a temperature $\leq 50^{\circ} \mathrm{C}$ was favourable for the production of a homogenous product as shown in
Table 1. This positive effect could be explained by a better homogeneous expansion of the clay layers, which favours the diffusion of ions in the interlamellar space. At higher temperature $\left(75^{\circ} \mathrm{C}\right.$ and $100^{\circ} \mathrm{C}$ ), a product with a non-crystalline structure was obtained (Figure 1). The broadness of the 001 diffraction peak is widely reported in the literature [38,52]. This indicates a poorly ordered structure showing the presence of different polymer species (irregular intercalation) and possible delamination of the clay structure. Fetter et al. Reported that the expected zirconium species present, among others, in solution is the hydroxycation $\left[\mathrm{Zr}_{4} \mathrm{OH}_{8}\left(\mathrm{H}_{2} \mathrm{O}\right)_{16}\right]^{8+}$, which rapidly polymerizes to form other species [26]. Then the montmorillonites are expected to be intercalated with different sizes causing the irregular staking of the clay layers. Farfan-Torres et al. reported that samples prepared at $100^{\circ} \mathrm{C}$ is an amorphous solid [16]. And he observed that there is an increase in the $\mathrm{ZrO}_{2}$ loading for higher temperature, but with alteration of the clay structure, same behavior obtained by us.

To avoid further degradation of the clay, as shown in Table 1 , the temperature must be between $25^{\circ} \mathrm{C}$ and $50^{\circ} \mathrm{C}$ to favor the polymerization of zirconium complex.

\begin{tabular}{|c|c|c|}
\hline & $d_{001}(\AA)$ & \\
\hline & $25^{\circ} \mathrm{C}$ & $550^{\circ} \mathrm{C}$ \\
\hline Na-Bent & 12 & 10 \\
\hline $\mathrm{Zr}_{25}$-Bent & 19.7 & 18.2 \\
\hline $\mathrm{Zr}_{40}$-Bent & 21.2 & 19.4 \\
\hline $\mathrm{Zr}_{50}$-Bent & 21 & 19.5 \\
\hline $\mathrm{Zr}_{75}$-Bent & delaminated & delaminated \\
\hline $\mathrm{Zr}_{100}$-Bent & delaminated & delaminated \\
\hline
\end{tabular}

Table 1: Basal spacing of $\mathrm{Zr}-\mathrm{Bent}$ at $25^{\circ} \mathrm{C}$ and at $550^{\circ} \mathrm{C}$.

Chemical analysis: The evolution of the $\mathrm{ZrO}_{2}$ introduced by pillaring process between layers as function of the different temperature is shown in Table 2. The $\mathrm{ZrO}_{2}$ percentage of the $\mathrm{Zr}$-Bent prepared at a temperature between $25^{\circ} \mathrm{C}$ and $50^{\circ} \mathrm{C}$ are almost the same. In fact, the $\mathrm{ZrO}_{2}$ percentages are $16.7 \%, 17.1 \%$ and $17.3 \%$ for $\mathrm{Zr}_{25^{-}}$ Bent, $\mathrm{Zr}_{40}$-Bent and $\mathrm{Zr}_{50}$-Bent samples respectively. Concerning the samples prepared at higher temperature, there is an increase in $\mathrm{ZrO}_{2}$ loading. The maximum percentage of $\mathrm{ZrO}_{2}$ introduced is reached with $\mathrm{Zr}_{75}$-Bent and $\mathrm{Zr}_{100}$-Bent samples (28 and $31 \%$ respectively). Two hypotheses may be proposed to explain the increase in the amount of zirconium: (i) the excess of pillaring agent may be adsorbed on the interlayer and external surfaces as neutral species $\left(\mathrm{Zr}_{4}(\mathrm{OH})_{16}\right)$ or $\mathrm{Zr}\left(\mathrm{OH}_{4}\right)$ (ii) a modification of the zirconium pillars by hydrolysis and/or polymerization due to the augmentation of temperature was produced [16,21]. Given broadness of the 001-diffraction peak obtained in the case of the $\mathrm{Zr}_{75}$-Bent and $\mathrm{Zr}_{100}$-Bent samples, it seems likely that the large amount of polycations introduced may be related to the formation of the neutral species rather than the form or arrangement of the pillars. The fixed zirconium exchanged is the quantity of $\mathrm{Zr}$ that remains linked to the structure after calcination and, in consequence, is not exchangeable with another cation if PILCs are redispersed in water. The quantity of the fixed zirconium exchanged was measured by a method similar to that used by Yamanaka and Brindley using $\mathrm{CaCl}_{2}$ solution [21]. In this way, the pillared samples, are redispersed in $\mathrm{NaCl}(1 \mathrm{M})$ solution. Results show that the $\mathrm{Zr}$ fixed is not exchangeable with $\mathrm{Na}^{+}$cation when PILCs are redispersed in $\mathrm{NaCl}(1 \mathrm{M})$ solution except for samples prepared with a temperature equal $75^{\circ} \mathrm{C}$ or $100^{\circ} \mathrm{C}$ (Table 2). The chemical analysis data of $\mathrm{Zr}_{75^{-}}$-Bent and $\mathrm{Zr}_{100^{-}}$-Bent) solids, after dispersing in the $\mathrm{NaCl}$ solution $(1 \mathrm{M})$, showed that about half of zirconium was detected in the solution of $\mathrm{NaCl}$. This amount was removed by exchanged reaction (Table 2). So, the large amount of polycations introduced may be related to the formation of the neutral species rather than the form or arrangement of the pillars. 
Citation: Mnasri-Ghnimi S, Frini-Srasra N (2017) Effect of Temperature Synthesis on the Catalytic Performance of Zirconium Pillared Interlayered
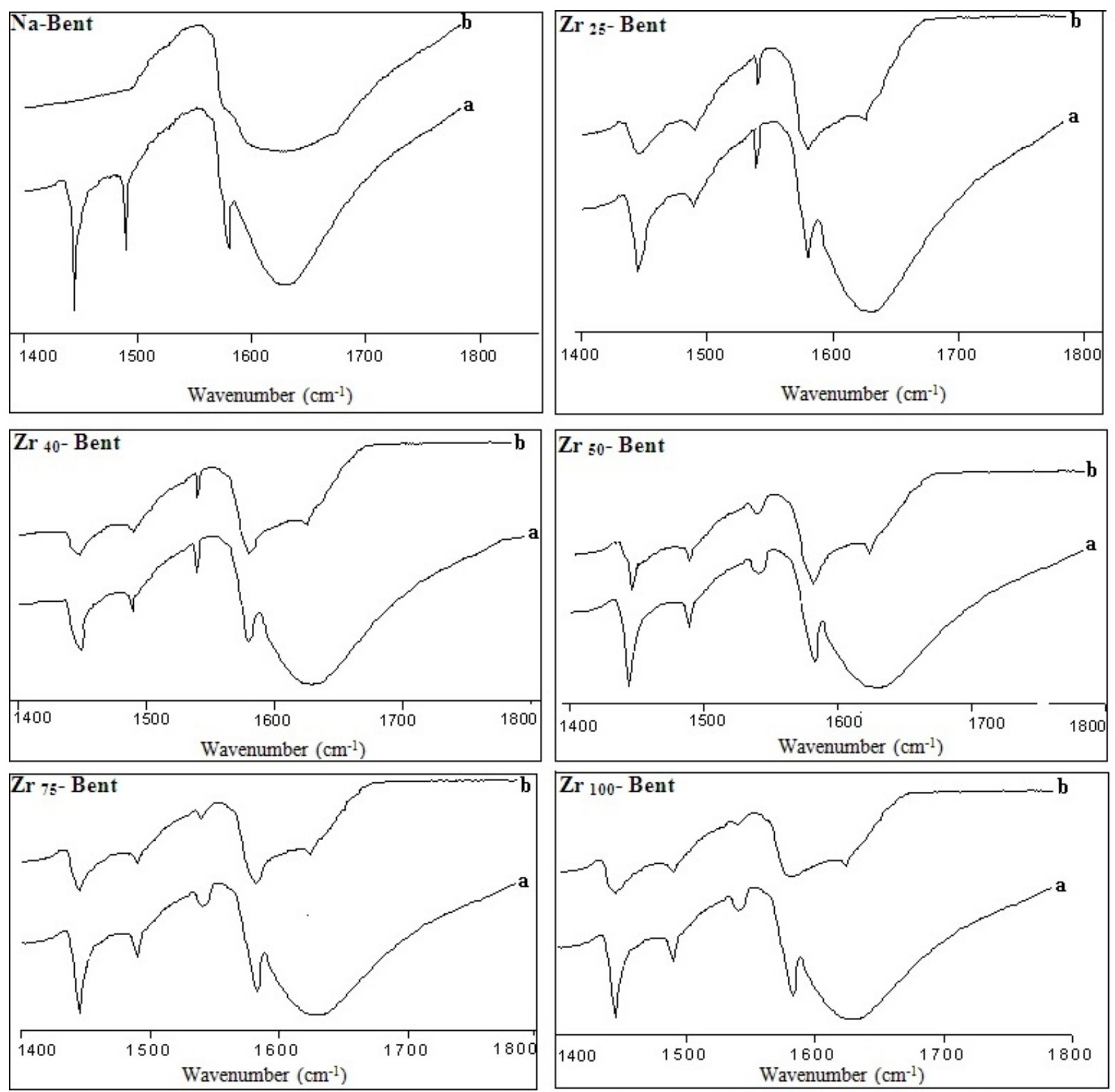

Figure 1: FT-IR spectra of n-Butylamine adsorbed on Na-Bent and Zr- Bent (a: treated at $25^{\circ} \mathrm{C}$; b: treated at $400^{\circ} \mathrm{C}$ ).

CEC: The residual cation exchange capacity (CEC) of calcined samples are presented in Table 3. It has to be noted that residual CEC are rather small in comparaison with initial CEC of Na-Bent (78 meq/100 $\mathrm{g}$ of clay). It is clear from the Table 3 that the residual CEC decreases as a function of the total $\mathrm{ZrO}_{2}$ fixed between layers (Table 2). The high residual CEC for $\mathrm{Zr}_{75}$-Bent and $\mathrm{Zr}_{100}$-Bent samples (41 and $44 \mathrm{meq} / 100 \mathrm{~g})$ and the decrease of the zirconium amount after its redispersion in the $1 \mathrm{M} \mathrm{NaCl}$ solution (Table 2) prove the existence of a part of zirconium that is not irreversibly fixed to the structure. This behaviour could be explained as a certain amount of $\mathrm{Zr}$ that may be adsorbed as a neutral species such as $\mathrm{Zr}_{4}(\mathrm{OH})_{16}$ [21]. The existence of those neutral species in the interlamellar space explains the amorphous structure detected.

\begin{tabular}{|l|l|l|l|l|l|l|l|l|l|}
\hline & $\mathrm{SiO}_{2}$ & $\mathrm{Al}_{2} \mathrm{O}_{3}$ & $\mathrm{Fe}_{2} \mathrm{O}_{3}$ & $\mathbf{M g O}$ & $\mathrm{CaO}$ & $\mathrm{K}_{2} \mathrm{O}$ & $\mathrm{Na}_{2} \mathrm{O}$ & $\mathrm{ZrO}_{2}$ & $\mathbf{Z r O}_{2}{ }^{*}(\mathbf{W t}, \%)$ \\
\hline Na-Bent & 61.38 & 24.8 & 8.03 & 1.38 & 0.13 & 1.4 & 3.06 & 0 & 0 \\
\hline
\end{tabular}


Citation: Mnasri-Ghnimi S, Frini-Srasra N (2017) Effect of Temperature Synthesis on the Catalytic Performance of Zirconium Pillared Interlayered Clays for Phenol Oxidation. Mod Chem Appl 5: 238. doi:10.4172/2329-6798.1000238

Page 5 of 9

\begin{tabular}{|l|l|l|l|l|l|l|l|l|l|}
\hline $\mathrm{Zr}_{25}$-Bent & 52.09 & 20.34 & 7.59 & 1.37 & 0.12 & 1.19 & 0.64 & 16.71 & 16.5 \\
\hline $\mathrm{Zr}_{40}$-Bent & 52.08 & 20.37 & 7.58 & 1.36 & 0.09 & 1.16 & 0.24 & 17.1 & 17 \\
\hline $\mathrm{Zr}_{50}$-Bent & 52.07 & 20.36 & 7.55 & 1.31 & 0.11 & 1.15 & 0.34 & 17.3 & 17 \\
\hline $\mathrm{Zr}_{75}$-Bent & 44.5 & 18.31 & 6.54 & 1.3 & 0.11 & 1.11 & 0.14 & 28 & 15.7 \\
\hline $\mathrm{Zr}_{100}$-Bent & 43 & 16.98 & 6.59 & 1.22 & 0.09 & 1.12 & 0.13 & 31 & 15.3 \\
\hline
\end{tabular}

Table 2: Chemical composition of Na-Bent-G and other pillared samples.

${ }^{*}$ After exchange with $\mathrm{NaCl}(1 \mathrm{M})$.

\begin{tabular}{|c|c|c|c|c|c|}
\hline Samples & SBET $\left(m^{2} g^{-1}\right)$ & $S_{\mu p}\left(m^{2} g^{-1}\right)$ & $V_{p}\left(\mathrm{~cm}^{3} \mathbf{g}^{-1}\right)$ & $V_{\mu p}\left(\mathrm{~cm}^{3} \mathrm{~g}^{-1}\right)$ & $\operatorname{CEC}(\mathrm{meq} / 100 \mathrm{~g})$ \\
\hline Na-Bent & 107 & 40 & 0,15 & 0,021 & 78 \\
\hline $\mathrm{Zr}_{25}$-Bent & 200 & 132 & 0,21 & 0,063 & 24 \\
\hline $\mathrm{Zr}_{40}$-Bent & 250 & 183 & 0,21 & 0,067 & 22 \\
\hline $\mathrm{Zr}_{50}$-Bent & 247 & 185 & 0,21 & 0,069 & 22 \\
\hline $\mathrm{Zr}_{75}$-Bent & 180 & 81 & 0,16 & 0,045 & 41 \\
\hline $\mathrm{Zr}_{100}-$ Bent & 190.6 & 90 & 0.16 & 0.033 & 47 \\
\hline
\end{tabular}

Table 3: Textural properties and CEC of starting material and Zr-PILCs.

Specific surface area and porosity: Figure 2 shows the adsorption desorption isotherms of some samples. The adsorption isotherms are of type I in the Brunauer, Deming, Deming and Teller (BDDT) classification at low pressures. All samples show a hysteresis loop type $\mathrm{H} 3$ in the IUPAC classification. The specific surface area (SBET) and microporosity of starting and modified clays are included in Table 3. For the initial bentonite, almost all the surface area results from pores in the mesopore size range. In contrast, for the pillared clays, an important portion of the specific surface area depends on micropores $[53,54]$. As expected, the presence of zirconium pillars produces important modifications in the specific surface area values. Almost, the intercalation with zirconium polycation caused a noticeable increase of the specific surface areas. The increase of surface area for the pillared samples is essentially related to the creation of micropores by the pillaring process and confirms that the pillar species used during preparation had entered between the clay layers, increasing the nitrogen accessibility. The resulting surface areas of $\mathrm{Zr}_{40}$-Bent and $\mathrm{Zr}_{50}$-Bent were larger than that prepared under conventional preparation $\left(\mathrm{Zr}_{25}\right.$-Bent). So, the preparation of zirconium pillars at 40 or $50^{\circ} \mathrm{C}$ was favorable for the production of microporous product. However, heating the zirconium solution at higher temperature (75 and $100^{\circ} \mathrm{C}$ ) produces a low specific surface area. This behavior can imply that these samples have lower accessibility to the $\mathrm{N}_{2}$, which is due to the smaller size of the pores caused by blocking of the interlayer spacing. This correlates well with the result given by XRD data which indicates the presence of amorphous products obtained with $75^{\circ} \mathrm{C}$ and $100^{\circ} \mathrm{C}$. Under this preparation condition, dissolution of clay with the formation of colloidal silica could take place, as reported in early studies concerning acid activation of clay [55].
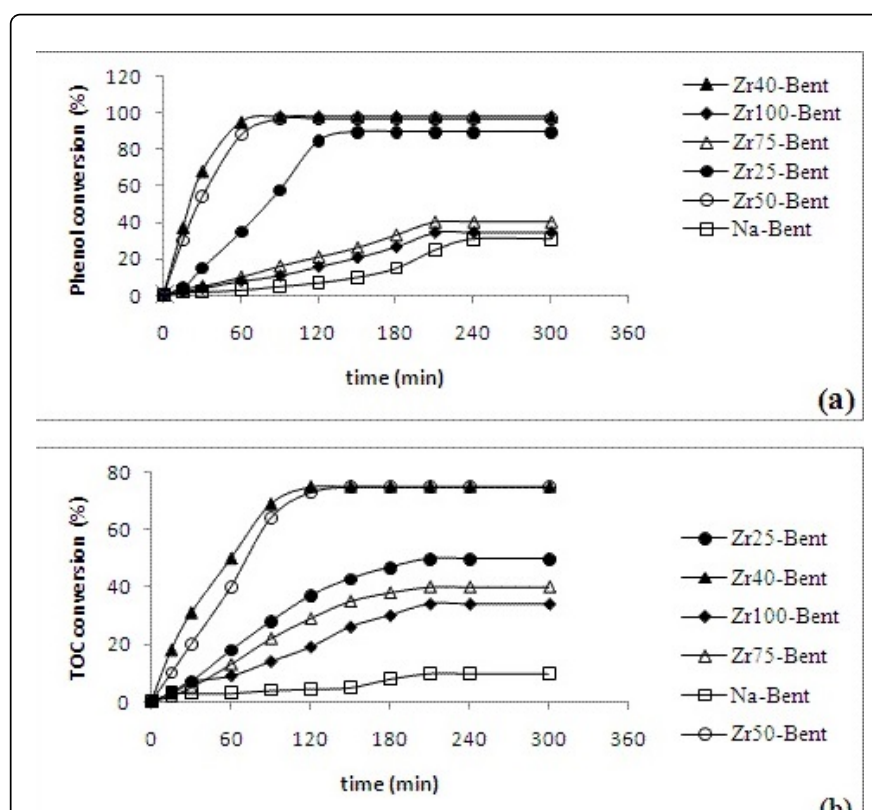

(b)

Figure 2: Catalytic activity for different catalyst in the phenol (a) and TOC (b) conversion in diluted aqueous medium at atmospheric pressure and at $25^{\circ} \mathrm{C}$.

Acidity: The origin of the electrical charge of bentonite is of two kinds: a permanent charge $\sigma \mathrm{O}$ created by isomorphic substitution of $\mathrm{Al}^{3+}$ for $\mathrm{Si}^{4+}$ in mineral structure and a variable charge $\sigma \mathrm{H}(\mathrm{pH}$ depending) on the edge resulting from proton adsorption/desorption reaction on surface hydroxyl groups. Depending on $\mathrm{pH}$, these surfaces 
can bear net negative, or positive, or no charge. The $\mathrm{pH}$ where the net total particle charge is zero is called the point of zero charge (PZC), which is one of the most important parameters used to describe variable charge surfaces. An example of the curve $\sigma \mathrm{Hvs}$. $\mathrm{pH}$ for $\mathrm{Na}-$ bent and $\mathrm{Zr}_{25}$ - Bent samples at three different ionic strengths is shown in Figure 3. The point of zero charge (PZC) and the number of acid centres in Na-Bent-G and modified clay, determined following the method of Sposito, are reported in Table 4 [50]. The PZC values of pillared samples are lower than the PZC of starting clay, the acidity of the clay is enhanced by pillaring. The intercalation of $\mathrm{Zr}$ species produced a shift of PZC from 7.3 for Na-Bent clay to [4.2-5.3] for the $\mathrm{Zr}$-Bent pillared sample. This value is in good agreement with the PZC value of $\mathrm{ZrO}_{2}$ reported in the literature, which ranges from 4 to 5 [56]. The PZC values depend directly on the amount of zirconium introduced into the clay. This shows that the acidity increases with the amount of the fixed zirconium exchanged. $\mathrm{Zr}_{40^{-}}$Bent and $\mathrm{Zr}_{50^{-}}$Bent samples have lower PZC and therefore show higher surface acidity. Preparation of $\mathrm{Zr}$-solution at a temperature up to $50^{\circ} \mathrm{C}$ reduces the acidity of the resulting catalyst.

Based on the total acid site numbers, the $\mathrm{Zr}_{50}$ sample has the highest total acidity $(1.75 \mathrm{mmol} / \mathrm{g})$. We notice that this sample is the richest in zirconium. The acidity found by us for zirconium pillared clay using $\mathrm{ZrCl}_{4}$ is higher than that reported by Toranzo et al. which reaches 0.66 and $0.87 \mathrm{mmol} \mathrm{H}^{+} / \mathrm{g}$ (of bentonite) when using zirconium acetate and zirconyl $\left(\mathrm{ZrOCl}_{2}\right)$ respectively as precursors [57].

To verify the PZC values estimated by the potentiometric method, we also determined the PZC of different samples using mass titration according to the method described by Noh and Schwartz [51]. As is shown in Figure 3 , the $\mathrm{pH}$ is gradually changing with the addition of a solid mineral and asymptotically approaches the limiting value. The $\mathrm{pH}$ thus estimated defined the PZC of the solid. The PZC values at different $\mathrm{pH}$ are reported in Table 4 and marked with arrows in Figure 3. It is possible to deduce here that there is very good agreement between acid- base potentiometric titrations and mass titration.

The infrared spectra of N-butylamine adsorbed on the original clay and $\mathrm{Zr}$-Bent after evacuation at different temperatures. According to Awate et al., the bands at 1450 and $1590 \mathrm{~cm}^{-1}$ are commonly assigned to Lewis acidity, the one at $1490 \mathrm{~cm}^{-1}$ is mainly attributed to both Lewis and Brönsted acidity, and the peak at $1545 \mathrm{~cm}^{-1}$ and the shoulder of the IR band at $1639 \mathrm{~cm}^{-1}$ are due to Brönsted acidity [27]. Ruiz et al. also reported that $n$-butylamine thermodesorption give results similar to pyridine thermodesorption [58].

The results of surface acidity measurements indicated that the modified forms of clay exhibited better Bronsted and Lewis acidity when compared to their starting form, the Na-Bent sample, which presents only weak Lewis acid sites at $298 \mathrm{~K}$. The acidity of Zr-PILCs may arise from the hydroxyl groups attached to $\mathrm{Zr}$ and the structural hydroxyl groups in the PILC [59-61]. During calcination, ion exchanged $\mathrm{Zr}$ poly-hydroxy-cation is converted into hydrated $\mathrm{ZrO}_{2}$ pillars and structural hydroxyl groups attached to $\mathrm{Al} / \mathrm{Mg}$ are formed [35]. On thermal treatment at $673 \mathrm{~K}$, a slight reduction in the intensity of the peaks of both Bronsted and Lewis acidity was observed in the case of all samples. This indicates stronger acidity of those samples. Farfan-Torres et al. reported in earlier study that the presence of amorphous phases suggests the formation of Bronsted acid sites on the solids calcined at $673 \mathrm{~K}$ [16].

The Bronsted/Lewis (B/L) ratio were obtained by integration of the area of the adsorption bands shown in Figure 3. The peak areas were used to measure the intensity of the bands. According to Grim, only bands at $1545 \mathrm{~cm}^{-1}$ (Bronsted acidity) and at $1448 \mathrm{~cm}^{-1}$ (Lewis acidity) have to be taken into account to evaluate the two types of acidity. The $\mathrm{B} / \mathrm{L}$ ratios at 298 and $673 \mathrm{~K}$ are reported in Table 5 . As it can be seen, the $\mathrm{B} / \mathrm{L}$ ratio decreases for all samples after thermal treatment. For the $\mathrm{B} / \mathrm{L}$ ratio at $673 \mathrm{~K}$, it is notably high in the case of $\mathrm{Zr}_{40}$ - Bent and $\mathrm{Zr}_{50^{-}}$ Bent.
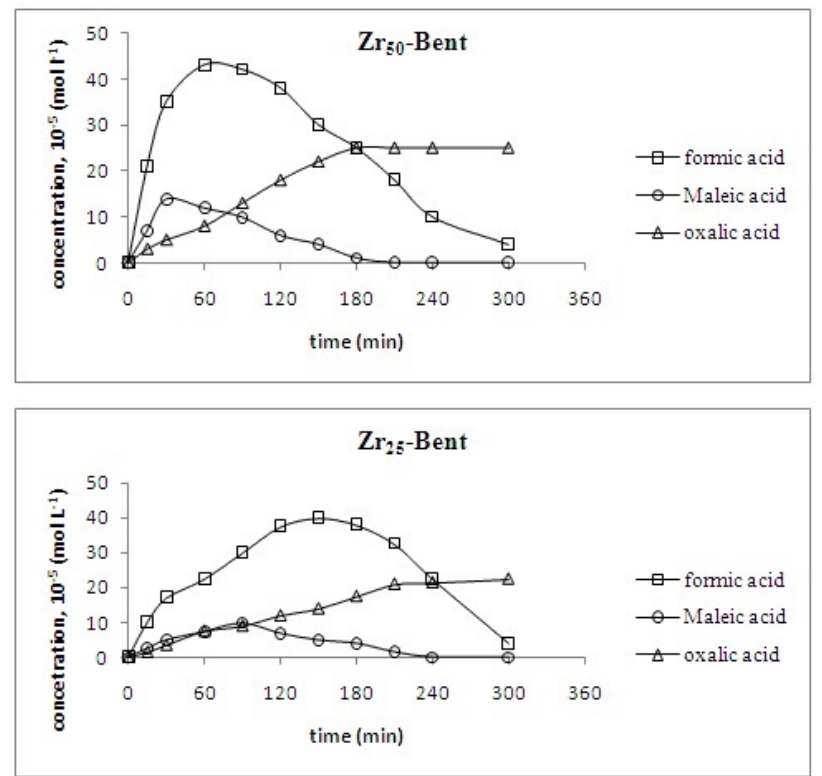

Figure 3: Time-evolution curves of aromatic intermediates from phenol with $\mathrm{Zr}_{25}$ - Bent and $\mathrm{Zr}_{50}$ - Bent.

\begin{tabular}{|l|l|l|l|}
\hline & PZC (mass titration) & PZC (potentiometric titration) & Acid center (mmol/g) \\
\hline Na-Bent & 7.31 & 7.33 & 0.76 \\
\hline$Z_{25}$-Bent & 4.73 & 4.71 & 1.21 \\
\hline$Z_{40}$-Bent & 4.22 & 4.25 & 1.65 \\
\hline$Z_{50}$-Bent & 4.23 & 4.26 & 1.75 \\
\hline$Z_{75}$-Bent & 4.91 & 4.98 & 0.93 \\
\hline
\end{tabular}




\begin{tabular}{|l|l|l|l|}
\hline $\mathrm{Zr}_{100}$-Bent & 5.31 & 5.33 & 0.88 \\
\hline
\end{tabular}

Table 4: $\mathrm{B} / \mathrm{L}$ ratio values of $\mathrm{Na}-\mathrm{Bent}$ and $\mathrm{Zr}$-Bent obtained at $25^{\circ} \mathrm{C}$ and $400^{\circ} \mathrm{C}$.

\begin{tabular}{|c|c|c|c|c|c|c|}
\hline & Na-Bent & $\mathrm{Zr}_{25}$-Bent & $\mathrm{Zr}_{40}$-Bent & $\mathrm{Zr}_{50}$-Bent & $\mathrm{Zr}_{75}$-Bent & $\mathrm{Zr}_{100}-$ Bent \\
\hline$B / L\left(25 C^{\circ}\right)$ & 0 & 0.29 & 0.33 & 0.4 & 0.21 & 0.23 \\
\hline$B / L\left(400 C^{\circ}\right)$ & 0 & 0.25 & 0.3 & 0.38 & 0.18 & 0.19 \\
\hline
\end{tabular}

Table 5: PZC values obtained by mass titration.

\section{Catalytic activities}

An important characteristic is the improved catalytic sites that influence the catalysis rate.

Figure 2 shows the results obtained for phenol conversion and total organic carbon TOC reduction with the different catalyst. It is clearly seen that the increase of the temperature of solution preparation of these pillared clays drastically increases their activity for phenol oxidation. The $\mathrm{Zr}_{40}$-Bent and $\mathrm{The} \mathrm{Zr}_{50}$-Bent show a higher activity than the corresponding $\mathrm{Zr}_{25}$-Bent ones prepared under ambiant temperature. With the $\mathrm{Zr}_{40}$-Bent and $\mathrm{The} \mathrm{Zr}_{50}$-Bent, almost complete phenol conversion (98\%) is reached in $1 \mathrm{~h}$ whereas the $\mathrm{Zr} 25$-Bent leads to no more than $35 \%$ at the same time and complete conversion (90\%) requires more than $2.5 \mathrm{~h}$ of reaction. When the solids were prepared at a temperature up to $50^{\circ} \mathrm{C}$ there was a decrease of the phenol conversion (Figure 2). The lowest activity and selectivity towards the formation of $\mathrm{CO}_{2}$ and $\mathrm{H}_{2} \mathrm{O}$ were achieved with the $\mathrm{Zr}_{100}$-Bent clay (35\%). This variation of activity among the different catalysts can be explained on the basis of their surface area and surface acidity. Amorphous samples ( $\mathrm{Zr}_{75}$-Bent and The $\mathrm{Zr}_{100}$-Bent) have lower surface area and higher PZC as compared to the crystalline forms and therefore show lower catalytic activity.

Another trend is that the increased $\mathrm{Zr}$ content is linearly related with the increased reaction rate. The existence of $\mathrm{Zr}$ catalytic sites helps to enhance the interaction between the phenol and catalytic sites. After further comparison with the total acidity and surface area data, the catalytic activity is linearly. For example, $\mathrm{Zr}_{40}$-Bent and The $\mathrm{Zr}_{50}$-Bent have a higher total acidity and have the highest rate compared to $\mathrm{Zr}_{75^{-}}$ Bent catalyst, with the most probable reason being the lower specific surface area with lower $\mathrm{Zr}$ content. In addition, increasing the $\mathrm{Zr}$ content enhanced the reaction rate due to the contribution of the $\mathrm{ZrO}_{2}$ particles that act as active sites to generate ${ }^{\circ} \mathrm{OH}$. The analysis of the effect of surface acidity on the radical mechanism indicated that the total acidity and L/B on the surface might be the main factors affecting the reaction rate. In fact, the adsorption-desorption mechanism is an important step in heterogeneous catalysis and is influenced by the intrinsic acidity of the solid catalyst $[60,62]$.

TOC reduction is, in all the cases, significantly lower than phenol conversion indicating that oxidation of phenol proceeds through the formation of different intermediates and the final result is far from complete mineralization, namely oxidation to $\mathrm{CO}_{2}{ }^{+} \mathrm{H}_{2} \mathrm{O}$. he maximum TOC reduction reaches $75 \%$ after $2 \mathrm{~h}$ in the case of $\mathrm{Zr}_{40^{-}}$ Bent and $\mathrm{Zr}_{50}$-Bent and close to $50 \%$ for $\mathrm{Zr}_{25}$-Bent after $3.5 \mathrm{~h}$, which means that significant amounts of intermediates still remain in solution. The $\mathrm{Zr}_{75}$-Bent and $\mathrm{Zr}_{100}$-Bent required $4 \mathrm{~h}$ to reach a plateau with a $40 \%$ and $34 \%$ of TOC conversion.
Various intermediate compounds such as catechol can be detected during the reaction showing that phenol oxidation reaction proceeds via well-known reactions $[59,63,64]$. According to the reaction pathway carried out by Devlin and Harris, the aromatic intermediates evolve to carboxylic acids, the distribution of which can be seen in Figure 3 [65]. In all the case, formic acid is the main product of this group of intermediates. In fact, the selectivity for formic acid is observed to be highest in all varied catalysts. Formic acid is more dominant in the product, showing a remarkable maximum concentration value and then a decrease due to mineralization. The trend for selectivity for a one product is similar to the trend observed by $[64,66]$.

\section{Conclusion}

A Zirconium pillared bentonite with varied synthesis temperature has been prepared. It is found that synthesis temperature affects the physicochemical characteristics of material as shown by the zirconia crystal formation at higher $\mathrm{Zr}$ content, change in specific surface and porosity while total surface acidity and L/B ratio parameter are varied with temperature. Solids synthesized through this means are catalytically active in a reaction with high environmental impact; the reaction for the oxidation of phenol in diluted aqueous medium. The catalysts based on pillared clays prepared at a temperature under $50^{\circ} \mathrm{C}$ showed a higher activity for phenol conversion and TOC removal.

\section{References}

1. Chorkendorff I, Niemantsverdriet JW (2003) Concepts of Modern Catalysis and Kinetics. Wiley-VCH, Weinheim, Germany, 12: 377-382.

2. Chirchi L, Ghorbel A (2002) Use of various Fe-modified montmorillonite samples for 4-nitrophenol degradation by $\mathrm{H}_{2} \mathrm{O}_{2}$. Appl Clay Sci 21: 271-276.

3. Santos A, Yustos P, Quintanilla A, Rodriguez S, Garcia-Ochoa F (2002) Route of the catalytic oxidation of phenol in aqueous phase. Appl Catal B 39: 97-113.

4. Catrinescu C, Teodosiu C, Macoveanu M, Miehe-Brendle J, Dred RL (2003) Catalytic wet peroxide oxidation of phenol over Fe-exchanged pillared beidellite. Water Res 37: 1154-1160.

5. Tomul F (2016) The effect of ultrasonic treatment on iron-chromium pillared bentonite synthesis and catalytic wet peroxide oxidation of phenol. Appl Clay Sci 120: 121-134.

6. Fortuny A, Font J, Fabregat A (1999) Water pollution abatement by catalytic wet air oxidation in a trickle bed reactor. Catal Today 53: 107-114.

7. Imamura S (1999) Catalytic and non-catalytic wet oxidation. Ind Eng Chem Res 38: 1743-1753.

8. Imamura S, Okuda K (1981) Effect of additives on the wet oxidation of phenol and acetic acid. Mizu Shori Gijutsu 22: 201-208. 
9. Luck F (1999) Wet air oxidation: past, present and future. Catal Today 53: $81-91$.

10. Mishra VS, Mahajani VV, Joshi JB (1995) Reviews: Wet air oxidation. Ind Eng Chem Res 34: 2-48.

11. Hamoudi S, Larachi F, Sayari A (1998) Wet oxidation of phenolic solutions over heterogeneous catalysts: degradation profile and catalyst behavior. J Catal 177: 247-258.

12. Hao OJ, Phull KK, Chen JM (1994) Wet oxidation of TNT red water and bacterial toxicity of treated waste. Water Res 28: 283-290.

13. Sanger AR, Lee TTK, Chuang KT (1992) Catalytic wet air oxidation in the presence of hydrogen peroxide. In: Smith KJ, Standford EC (eds.) Progress in Catalysis. Elsevier, Amsterdam, Netherland, pp: 197-201.

14. Carriazo JG, Guelou E, Barrault J, Tatiboue JM, Moreno S (2003) Catalytic wet peroxide oxidation of phenol over $\mathrm{Al}-\mathrm{Cu}$ or $\mathrm{Al}-\mathrm{Fe}$ modified clays. Appl Clay Sci 22: 303-308.

15. Najjar W, Azabou S, Sayadi S, Ghorbel A (2007) Appl Catal B 74: 11-18.

16. Farfan-Torres EM, Sham E, Grange P (1992) Pillared clays: Preparation and characterization of zirconium pillared montmorillonite. Catal Today 15: 515-526.

17. Cool P, Vansant EF (1996) Preparation and characterization of zirconium pillared laponite and hectorite. Microporous Mater 6: 27-36.

18. Chae HJ, Nam IS, Ham SW, Hong SB (2001) Physicochemical characteristics of pillared interlayered clays. Catal Today 68: 31-40.

19. Mnasri S, Frini-Srasra N (2012) Influence of aluminium incorporation in the preparation of zirconia-pillared clay and catalytic performance in the acetalization reaction. Clay Minerals 47: 453-463.

20. Kooli F, Liu Y, Hbaieb K, Al-Faze R (2016) Characterization and catalytic properties of porous clay heterostructures from zirconium intercalated clay and itspillared derivatives. Microporous Mesoporous Mater 226: 482-492.

21. Yamanaka S, Brindley GW (1979) High area solids obtained by reaction of montmorillonite with zirconyl chloride. Clays Clay Miner 27: 119-124.

22. Bartley GJJ, Burch R (1985) Zr-containing pillared interlayer clays. Part III. Influence of method of preparation on the thermal and hydrothermal stability. Appl Catal 19: 175-185.

23. Ohtsuka K, Hayashi Y, Suda M (1993) Microporous ZrO [sub 2]-pillard clays derived from three kinds of $\mathrm{Zr}$ polynuclear ionic species. Chem Mater 5: 1823.

24. Vasundhara S, Varinder S, Goverdhan LK (2004) Ultrasound and microwave activated preparation of $\mathrm{ZrO}_{2}$-pillared clay composite: catalytic activity for selective, solventless acylation of 1,n-diols. J Mol Catal A: Chemical 210: 119-124.

25. De Andies AM, Merino J, Galvan JC, Ruiz-Hitzky E (1999) Ultrasound and microwave activated preparation of $\mathrm{ZrO}_{2}$-pillared clay composite: catalytic activity for selective, solventless acylation of 1,n-diols. Mat Res Bull 34: 541.

26. Fetter G, Hernandez V, Rodriguez V, Valenzuela MA, Lara VH, et al. (2003) Effect of microwave irradiation time on the synthesis of zirconia pillared clays. Mater Lett 57: 1220-1223.

27. Awate SV, Waghmode SB, Agashe MS (2004) Synthesis, characterization and catalytic evaluation of zirconia-pillared montmorillonite for linear alkylation of benzene. Catalysis Communications, 5, 407-411.

28. Zhengping H, Zhu HY, Lu GQ (2003) Zr-Laponite pillared clay-based nickel catalysts for methane reforming with carbon dioxide Applied Catalysis A: General 242: 275-286

29. Guerra SR, Merat LMOC, San-Gil RAS, Dieguez LC (2008) Alkylation of benzene with olefins in the presence of zirconium-pillared clays. Catal Today 133: 223-230.

30. Gandia LM, Toranzo R, Vicente MA, Gil A (1999) Non-aggressive pillaring of clays with zirconium acetate. Comparison with alumina pillared clays. Appl Catal A: General 183: 23-33.

31. Dominguez JM, BotelloPozos JC, Ortega LA, Ramirez MT, SandovalFlores G, et al. (1998) Study of pillar precursors [Ga(III)-Al(III), $\mathrm{Ln}(\mathrm{III})-\mathrm{Al}(\mathrm{III}), \mathrm{Zr}(\mathrm{IV})]$ for hydrothermally stable pillared clays. Catal Today 43: 69-77.
32. McCabe RW (1996) Inorganic Materials. (2nd edn.) John Wiley and Sons, New York.

33. Vaccari A (1999) Clays and catalysis: a promising future. Appl Clay Sci 14: $161-198$

34. Gil A, Gandia LM, Vicente MA (2000) Recent advances in the synthesis and catalytic applications of pillared clays. Catal Rev Sci Eng 42: 145-212.

35. Cool P, Vansant EF, Poncelet G, Schoonheydt RA (2002) In: Sing K, Weitkamp J, Schuth F (eds.), Hand Book of Porous Solids. Wiley-VCH, Germany, pp: 1250-1264.

36. Mishra BG, Rao GR (2003) Influence of synthesis conditions and cerium incorporation on the properties of Zr-pillared clays. J Porous Mater 10: 93-103.

37. Bahranowskia K, Włodarczyka W, Wisła-Walshb E, Gaweła A, Matusika J, et al. (2015) [Ti,Zr]-pillared montmorillonite - A new quality with respect to Ti- and Zr-pillared clays. Microporous Mesoporous Mater 202: 155-164.

38. Maes N, Heylen I, Cool P, Vansant EF (1997) The relation between the synthesis of pillared clays and their resulting porosity. Appl Clay Sci 12: 43-60.

39. Chaabene SB, Bergaoui L, Ghorbel A, Lambert JF, Grange P (2004) In situ preparation of zirconium sulfate pillared clay: study of acidic properties. Appl Catal A: General 268: 25-31.

40. Mishra BG Rao GR (2004) Physicochemical and catalytic properties of Zr-pillared montmorillonite with varying pillar density. Microporous Mesoporous Mater 70: 43-50.

41. Rao GR, Mishra BG (2005) A comparative UV-vis-diffuse reflectance study on the location and interaction of cerium ions in $\mathrm{Al}-$ and $\mathrm{Zr}$ pillared montmorillonite clays. Mater Chem Phys 89: 110-115.

42. Merat LMOC, San-Gil RAS, Guerra SR, Dieguez LC, Caldarelli S, et al. (2007) A spectroscopic probe for combined acid and redox properties in acid catalysts. J Mol Catal A: Chemical 272: 298-305.

43. Yang RT, Tharappiwattananon N, Long RQ (1998) Ion-exchanged pillared clays for selective catalytic reduction of NO by ethylene in the presence of oxygen. Appl Catal B: Environ 19: 289-304.

44. Hutson ND, Hoekstra MJ, Yang RT (1999) Control of microporosity of Al2O3-pillared clays: effect of $\mathrm{pH}$, calcination temperature and clay cation exchange capacity. Microporous Mesoporous Mater 28: 447-459.

45. Bouchenafa-Sarb N, Khouli K, Mohammedi O (2007) Preparation and characterization of pillared montmorillonite: Application in adsorption of cadmium. Desalination 217: 282-290.

46. Lin Q, Hao J, Li J, Ma Z, Lin W (2007) Copperimpregnated Al-Cepillared clay for selective catalytic reduction of $\mathrm{NO}$ by $\mathrm{C}_{3} \mathrm{H}_{6}$. Catal Today 126: $351-358$.

47. Ksontini N, Najjar W, Ghorbel A (2008) Al-Fe pillared clays: Synthesis, characterization and catalytic wet air oxidation activity. J Phys Chem Solids 69: 1112-1115.

48. Jiang YX, Xiao M (2004) Preparation and properties of Al-PILC supportedSO42-/ $\mathrm{TiO} 2$ superacid catalyst. J Mol Catal A: Chem 213: 231-234.

49. Molina CB, Casas JA, Zazo JA, Rodriguez JJ (2006) A comparison of Al$\mathrm{Fe}$ and $\mathrm{Zr}$-Fe pillared clays for catalytic wet peroxide oxidation. Chem Eng J 118: 29-35.

50. Sposito G (1984) The Surface Chemistry of Soils. Oxford University Press, India.

51. Noh SJ, Schwartz AJ (1989) Estimation of the point of zero charge of sample oxide by mass titration. J Colloid Interface Sci 130: 157-164.

52. Colin JA, de los Reyes JA, Vazquez A, Montoya A (2005) Pillar effects in MoS2 catalysts supported on $\mathrm{Al}$ and $\mathrm{Zr}$ pillared clays in a hydrotreatment reaction: A preliminary study. Appl Surf Sci 240: 48-62.

53. Greeg SJ, Sing KSW (1991) Adsorption, Surface Area and Porosity. Academic Press, London.

54. Sing KSW, Everett DH, Haul RAW, Moscou L, Pierotti RA, et al. (1985) Modeling of Adsorption and Desorption in Pores of Simple Geometry Using Molecular Dynamics. Pure Appl Chem 57: 603. 
Citation: Mnasri-Ghnimi S, Frini-Srasra N (2017) Effect of Temperature Synthesis on the Catalytic Performance of Zirconium Pillared Interlayered Clays for Phenol Oxidation. Mod Chem Appl 5: 238. doi:10.4172/2329-6798.1000238

Page 9 of 9

55. Jackson ML (1963) Interlayering of expansible layer silicates in soils by chemical weathering. Clays Clay Miner 11: 29-46.

56. Haussonne JM, Carry C, Bowen P, Barton J (2005) Ceramiques et verres : Principes et techniques d’elaboration. Traite de Materiaux, Switzerland.

57. Toranzo R, Vicente MA, Banares-Munoz MA, Gandia LM, Gil A (1998) Pillaring of saponite with zirconium oligomers. Microporous Mesoporous Mater 173: 173-188.

58. Ruiz JAC, Melo DMA, Souza R, Alcazar LO (2002) Determination of total acid in palygorskite chemically modified by n-butylamine thermodesorption. Mater Res 5: 173-178.

59. Lambert J, Poncelet G (1997) Acidity in pillared clays: origin and catalytic manifestations. Topic Catal 4: 43-56.

60. Wu C, Kong Y, Gao F, Wu Y, Lu Y, et al. (2008) Synthesis, characterization and catalytic performance for phenol hydroxylation of Fe-MCM41 with high iron content. Microporous Mesoporous Mater 113: 163-170.
61. Pinnavaia TJ, Tzou M, Landau SD (1985) New chromia pillared clay catalysts. J Am Chem Soc 107: 2783-2785.

62. Valkaj KM, Wittine O, Margeta K, Granato T (2011). Phenol oxidation with hydrogen peroxide using $\mathrm{Cu} / \mathrm{ZSM}_{5}$ and $\mathrm{Cu} / \mathrm{Y}_{5}$ Catalysts. Pol J Chem Technol 13: 28-36.

63. Joglekar HS, Samant SD, Joshi JB (1991) Kinetics of wet air oxidation of phenol and substituted phenols. Water Res 25: 135-139.

64. Kulawong S, Prayoonpokarach S, Neramittagapong A, Wittayakun J (2011) Mordenite modification and utilization as supports for iron catalyst in phenol hydroxylation. J Indian Eng Chem 17: 346-351.

65. Devlin H, Harris I (1984) Mechanism of the oxidation of aqueous phenol with dissolved oxygen. Ind Eng Chem Fundation 23: 387-392.

66. Reddy EP, Davydov L, Smirniotis PG (2004) $\mathrm{TiO}_{2}$-loaded zeolites and MCM-41 in the sonophotocatalytic decomposition of aqueous organic pollutants the role of the support. Appl Catal B: Environ 42: 1-11. 